\title{
Pericarp, Leachate, and Carbohydrate Involvement in Thermoinhibition of Germinating Spinach Seeds
}

\author{
Daniel I. Leskovar ${ }^{1}$ and Virgil Esensee \\ Department of Horticultural Sciences, Texas Agricultural Experiment Station, Texas A\&M University, \\ 1619 Garner Field Road,Uvalde, TX 78801 \\ Helen Belefant-Miller \\ Oak Ridge National Laboratory, MS 6123, P.O. Box 2008, Oak Ridge, TN 37831
}

\begin{abstract}
AdDitional INDEX words. Spinacia oleracea, ABA, abscisic acid, alternating temperatures, dormancy, embryo, oligosaccharide, seedcoat

Abstract. Spinach (Spinacia oleracea L.) seed germination can be inhibited by high temperatures. An understanding of thermoinhibition in spinach is critical in predicting germination and emergence events. The purpose of this study was 3-fold: 1) to determine seed germination percentage and rate of spinach genotypes-'Cascade', 'ACX 5044', 'Fall Green', and 'ARK 88-354' - exposed to constant and alternating temperatures; 2) to determine the nature and extent of inhibition imposed by the pericarp; and 3 ) to investigate leachate and oligosaccharide involvement in thermoinhibition. Germination inhibition began at $>20^{\circ} \mathrm{C}$ constant temperature and was totally suppressed at $35^{\circ} \mathrm{C}$. Alternating temperatures at $30 / 15^{\circ} \mathrm{C}\left(12\right.$-hour day/12-hour night) resulted in greater germination than a constant $30^{\circ} \mathrm{C}$. The genotype sensitivity to supraoptimal temperatures was in the order of 'ARK 88-354' $\leq$ 'Fall Green' < 'ACX 5044' < 'Cascade', but the highly thermoinhibited 'Cascade' seeds retained the ability to germinate when shifted to lower incubation temperatures. The pericarp inhibited germination, since seeds deprived of the pericarp had $\approx 90 \%$ germination at $30{ }^{\circ} \mathrm{C}$. 'ACX 5044 ' and 'Cascade' had higher ABA content in the pericarp than 'ARK 88-354' and 'Fall Green'. Before imbibition at $30{ }^{\circ} \mathrm{C}$, raffinose levels in each genotype were in the order of 'ARK 88-354' > 'Fall Green' > 'Cascade'. After 48 hours of imbibition, sucrose and glucose levels were highest and raffinose levels were lowest in 'ARK 88-354' and 'Fall Green' seeds, while 'Cascade' seeds remained less active metabolically. These data suggest that the pericarp apparently acts as a physical barrier as well as a source of inhibitors during thermoinhibition.
\end{abstract}

Spinach (Spinacia oleracea) seed germination is inhibited by temperatures higher than $30^{\circ} \mathrm{C}$ (Heydecker and Orphanos, 1968). Spinach plantings in southwest Texas occur between August and December when temperatures typically average $36 / 20^{\circ} \mathrm{C}$ (maxi$\mathrm{mum} / \mathrm{minimum}$ ). Consequently, yields can be reduced by poor field emergence and by low and variable plant stands.

Fluctuating temperatures partially overcome primary dormancy acquired during seed development in Sorghum halepense (L.) Pers. (Benech Arnold et al., 1988) and Nicotiana tabacum L. (Bewley and Black, 1994). It is unknown whether alternating temperatures alleviate thermoinhibition in spinach genotypes, and whether seeds exposed to high temperatures lose their ability to germinate if transferred to lower temperatures. Pericarp removal promoted spinach seed germination at high temperatures (Atherton and Farooque, 1983a), but the mechanism, physical or chemical, is unclear. Removal of water soluble chemical inhibitors may be an important step to alleviate seed thermoinhibition, but it is unknown for spinach genotypes. Methods to remove seed inhibitors or to release seeds from thermodormancy include washing, scarification, and osmopriming (Atherton and Farooque, 1983b; Cantliffe et al., 1984; Hassell and Kretchman, 1997; Masuda and Konishi, 1993).

High levels of oligosaccharides may be an important mechanism to establish metabolic controls for seed germination(Vertucci

\footnotetext{
Received for publication 29 June 1998. Accepted for publication 28 Dec. 1998. We thank R. Sprague, J.C. Ward, and R.J. Santos for their laboratory assistance. Appreciation is also extended to Alf Christianson for providing seed materials Mention of a trademark, proprietary product or vendor does not constitute a guarantee or warranty of the product, nor does it imply approval or disapproval to the exclusion of other products or vendors that may also be suitable. The cost of publishing this paper was defrayed in part by the payment of page charges. Under postal regulations, this paper therefore must be hereby marked advertisement solely to indicate this fact.

${ }^{1}$ To whom reprint requests should be addressed.
}

and Farrant, 1995). Changes in carbohydrates occur during seed germination, with generally the monosaccharide content increasing and the oligosaccharide content decreasing (Vertucci and Farrant, 1995; Koster and Leopold, 1988). Oligosaccharides of higher degree polymerization (DP) may protect membranes and macromolecules in seeds from desiccation damage (Bernal-Lugo and Leopold, 1992). Evidence of carbohydrate metabolism in spinach seeds imbibed at supraoptimal temperatures is lacking, as well as the role of oligosaccharides of higher DP, such as sucrose and raffinose, in preventing thermoinhibited seeds going into thermodormancy.

The purpose of this study was to determine the extent of seed thermoinhibition in four spinach genotypes, the nature and level of inhibition imposed by the pericarp and seedcoat leachates, and to identify and quantify the level of soluble carbohydrates during thermoinhibition.

\section{Materials and Methods}

Germination at CONSTANT and alternating temperatures. Seed of 'Cascade' (hybrid), 'ACX 5044' (hybrid), and 'Fall Green' (open pollinated) (Alf Christianson Seed Co., Mount Vernon, Wash.) were placed on Whatman No. 1 and No. 3 filter papers in 9 -cm petri dishes. Five milliliters of distilled deionized water was initially added, and followed by additions of $0.5 \mathrm{~mL}$ as needed. Seeds were incubated for 2 weeks on a thermogradient table at constant $10,15,20,22,23,25,30$, and $35 \pm 1^{\circ} \mathrm{C}$. To determine whether alternating temperatures could alleviate thermoinhibition, the seeds were incubated at $25 / 15,30 / 15,35 / 15,30 / 20,35 / 20$, and $35 / 25^{\circ} \mathrm{C}(12-\mathrm{h}$ day/12-h night $)$ for 4 weeks. Controls at 20,25 , and $30{ }^{\circ} \mathrm{C}$ constant temperatures were also included.

The following experiment determined whether spinach seeds held at high temperature for a prolonged period of time lose their 


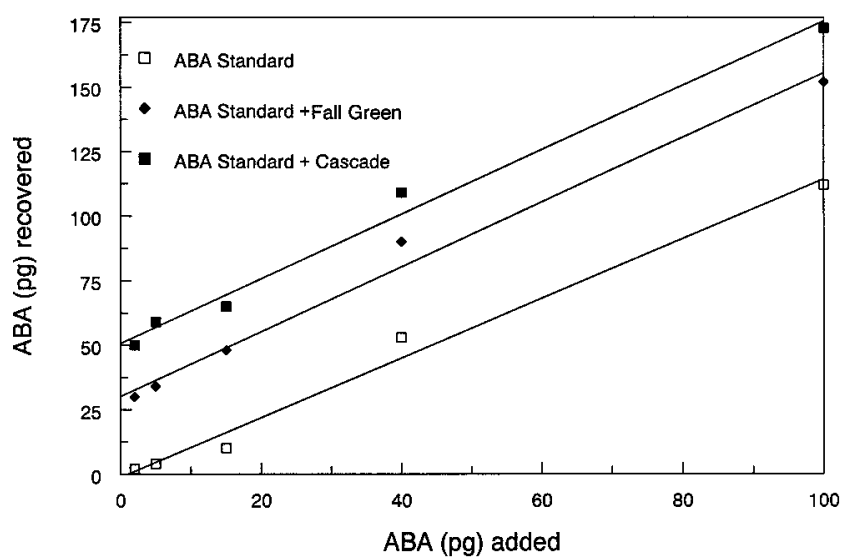

Fig. 1. Shifts in the ABA standard curve due to addition of spinach seed extracts. The amount of ABA was measured by indirect ELISA in samples containing only ABA standard (open squares, $\mathrm{y}=-0.800+1.168 \mathrm{x}, r^{2}=0.986$ ), ABA standard + 'Fall Green' extract (solid diamond, $\mathrm{y}=30.407+1.291 \mathrm{x}, r^{2}=0.984$ ), and ABA standard + 'Cascade' extract (solid square, $\mathrm{y}=50.703+1.264 \mathrm{x}, r^{2}=0.990$ ). Each point represents a mean $(n=4)$.

ability to germinate when returned to lower temperatures. 'Cascade' nontreated seeds, washed seeds (immersed in water at 10 ${ }^{\circ} \mathrm{C}$ for $4 \mathrm{~h}$, followed by surface disinfection with $2 \% \mathrm{NaOCl}$ for 10 min and rinsing three times with deionized water), and seeds only disinfected with $\mathrm{NaOCl}$ as described for washed seeds, were incubated at a constant $30^{\circ} \mathrm{C}$ for $10 \mathrm{~d}$ or $35^{\circ} \mathrm{C}$ for $7 \mathrm{~d}$, and then transferred to $18{ }^{\circ} \mathrm{C}$ for a total incubation time of $20 \mathrm{~d}$. The difference in the transfer time to $18^{\circ} \mathrm{C}$ was based on preliminary observations, where seed vigor was visibly reduced when seeds were previously incubated at $35^{\circ} \mathrm{C}$ for $>8 \mathrm{~d}$ or at $30^{\circ} \mathrm{C}$ for $>10$ d.

Pericarp role on germination. To evaluate whether thermoinhibition at $30^{\circ} \mathrm{C}$ is seedcoat and/or embryo imposed, seeds were treated as follow: a) pericarp removal (coatless or naked seeds); b) pericarp removed and placed on the same medium at a distance of about $\leq 5 \mathrm{~mm}$ from the embryo (spirally coiled around the attached perisperm); c) pericarp removed, embryo reinserted back into pericarp, d) slitted-pericarp seeds, and e) intact seeds. To remove the pericarp or seedcoat, seeds were placed on Whatman No. 3 filter paper in 9-cm petri dishes, and moistened with $5 \mathrm{~mL}$ of distilled deionized water for $10 \mathrm{~min}$. Individual seeds were then placed under a 40× magnification stereo microscope and pericarps were removed using a surgical blade and a sharp-point forceps. Slitting was carefully done with a surgical blade to a length of $\approx 1$ to $2 \mathrm{~mm}$ near the radicle end point, and seeds with visible embryo damage were discarded. The open pollinated genotype 'ARK 88-354' was also included in this test. Seeds were incubated for one week in darkness at a constant $30{ }^{\circ} \mathrm{C}$ and germinated seeds were counted at 2:00 PM daily.

Germination WITH EXogenouS ABA AND LEACHATE. To determine the high temperature sensitivity of 'Cascade' and 'ARK 88-354' to exogenous $\mathrm{ABA}$, pericarpless seeds were germinated in an incubator in the dark at $30 \pm 1^{\circ} \mathrm{C}$ for $7 \mathrm{~d}$. ABA (+/-cis, trans) (Sigma Chemical Co., St. Louis, Mo.) concentrations of $10^{-3}, 10^{-4}, 10^{-5}, 10^{-6}, 10^{-7}, 10^{-8}$, and $10^{-9} \mathrm{M}$ were prepared, and $5 \mathrm{~mL}$ of ABA solution was added to the filter paper initially, followed by additions of $0.5 \mathrm{~mL} \mathrm{ABA}$ solution at 2 and $4 \mathrm{~d}$.

To determine the effects of water soluble extracts on germination of spinach 'Cascade', 'ACX 5044', 'Fall Green', and 'ARK 88-354' seeds incubated at $30^{\circ} \mathrm{C}$, the following treatments were tested: a) intact seeds in distilled deionized water; b) leached seeds in distilled deionized water; c) leached seeds in leachates extracted from whole seeds of the same genotypes, d) embryos in leachates from whole seeds of the same genotypes; and e) embryos in deionized distilled water. Leached seeds and leachates were obtained by mixing $50 \mathrm{~g}$ of intact seeds of $\approx 7 \%$ moisture content with distilled water $(1: 4 \mathrm{w} / \mathrm{v})$ and stirring continuously for $1 \mathrm{~h}$ at $23^{\circ} \mathrm{C}$. The leachates were vacuum filtered using two No. 1 Whatman filter papers. For a bioassay, $120 \mathrm{~mL}$ of each extract was retained and the remainder was centrifuged at 2,500 rpm for 30 min, freeze dried, and assayed for ABA as described below.

To measure ABA content in pericarps, the pericarps were manually separated from intact dry seeds of 'Cascade', 'ACX 5044', 'Fall Green', and 'ARK 88-354' genotypes as described previously. Pericarp samples were $\approx 80$ to $160 \mathrm{mg}$ with four replications per cultivar. ABA was extracted from the pericarps in methanol containing butylated hydroxytoluene and assayed by an indirect ELISA (Belefant and Fong, 1989). Seed leachates from each genotype were also assayed for ABA content. When extracts were tested for interference by some substances in the binding of ABA to the monoclonal antibody (Crozier et al., 1985), the linearity or slope of the standard curves of ABA was not altered (Fig. 1). A similar procedure was used to determine ABA content in whole seeds, but due to high interference from substances in the perisperm, ABA was not measured.

EFFECT OF 'CASCADE' PERICARPS ON 'ARK 88-354' EMBRYos. To confirm the inhibition of 'Cascade' pericarps on 'Cascade' and 'ARK 88-354' embryos incubated at $30{ }^{\circ} \mathrm{C}$ in deionized distilled water, the following embryo treatment manipulations were tested: a) 'Cascade' embryo; b) 'Cascade' pericarp removed, embryo reinserted back into pericarp; c) 'Cascade' pericarp removed, 'ARK 88-354 embryo reinserted into 'Cascade' pericarp; d) 'ARK 88354' embryo; e) 'ARK 88-354' ' pericarp removed, embryo reinserted back into pericarp; and f) 'ARK 88-354' pericarp removed, 'Cascade' embryo reinserted into 'ARK 88-354' pericarp.

Soluble Carbohydrates. Carbohydrates were determined for 'Cascade', 'Fall Green' and 'ARK88-354' imbibed seeds at 30 and $36^{\circ} \mathrm{C}$. Seeds were sampled at various times over $96 \mathrm{~h}$, flash frozen with liquid $\mathrm{N}$, freeze-dried, ground to powder, trimethylsilyl (TMS) derivatized, and analyzed for oligosaccharide content by gas chromatography using a DB-1 capillary column with a glass insert (HP 5181-3316) used as a splitless liner. Runs were started at $160{ }^{\circ} \mathrm{C}$ oven temperature with the injector and detector at 350 ${ }^{\circ} \mathrm{C}$. The oven was programmed to hold for $4 \mathrm{~min}$ at $160{ }^{\circ} \mathrm{C}$, and then increased to $325^{\circ} \mathrm{C}$ at $8^{\circ} \mathrm{C}$ per min and held for $25 \mathrm{~min}$. Peaks were identified by using the internal standard 1-O-methyl- D-

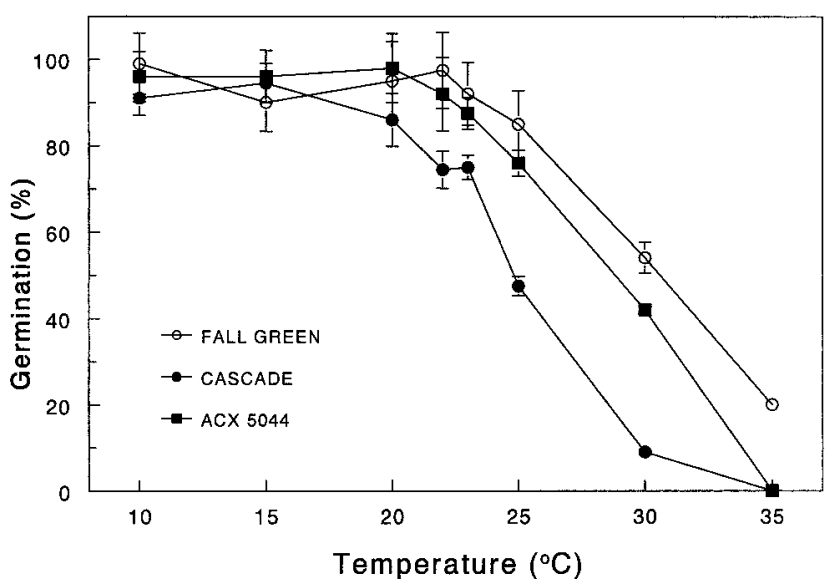

Fig. 2. Germination of spinach seeds incubated for $14 \mathrm{~d}$ at constant temperatures Each point represents a mean $(n=4) \pm$ SE (where larger than data point). 
Table 1. Germination of spinach seeds at alternating temperatures (12-h day/12-h night) for $14 \mathrm{~d}$.

\begin{tabular}{|c|c|c|c|c|c|c|}
\hline \multirow[b]{2}{*}{ Genotype } & \multicolumn{6}{|c|}{ Temp $\left({ }^{\circ} \mathrm{C}\right)$} \\
\hline & $25 / 15$ & $30 / 15$ & $35 / 15$ & $30 / 20$ & $35 / 20$ & $35 / 25$ \\
\hline & \multicolumn{6}{|c|}{ Germination (\%) } \\
\hline Fall Green & 94 & 90 & 58 & 90 & 90 & 70 \\
\hline ACX 5044 & 98 & 94 & 44 & 78 & 85 & 68 \\
\hline Cascade & 69 & 64 & 40 & 54 & 59 & 32 \\
\hline \multirow{2}{*}{$\operatorname{LSD}_{(0.05)}$} & 16 & 18 & --- & 18 & 17 & 22 \\
\hline & \multicolumn{6}{|c|}{$\mathbf{T}_{25 \%}(\mathbf{d})^{\mathbf{z}}$} \\
\hline Fall Green & 2.3 & 2.6 & 2.8 & 2.2 & 2.8 & 3.2 \\
\hline ACX 5044 & 3.6 & 3.8 & 7.9 & 3.9 & 6.0 & 7.2 \\
\hline Cascade & 6.9 & 7.9 & 9.1 & 8.9 & 8.9 & 10.8 \\
\hline $\operatorname{LSD}_{(0.05)}$ & 1.7 & 0.3 & 2.3 & 1.6 & 1.5 & 2.7 \\
\hline
\end{tabular}

${ }^{\mathrm{z}} \mathrm{T}_{25 \%}=$ Time to $25 \%$ germination.

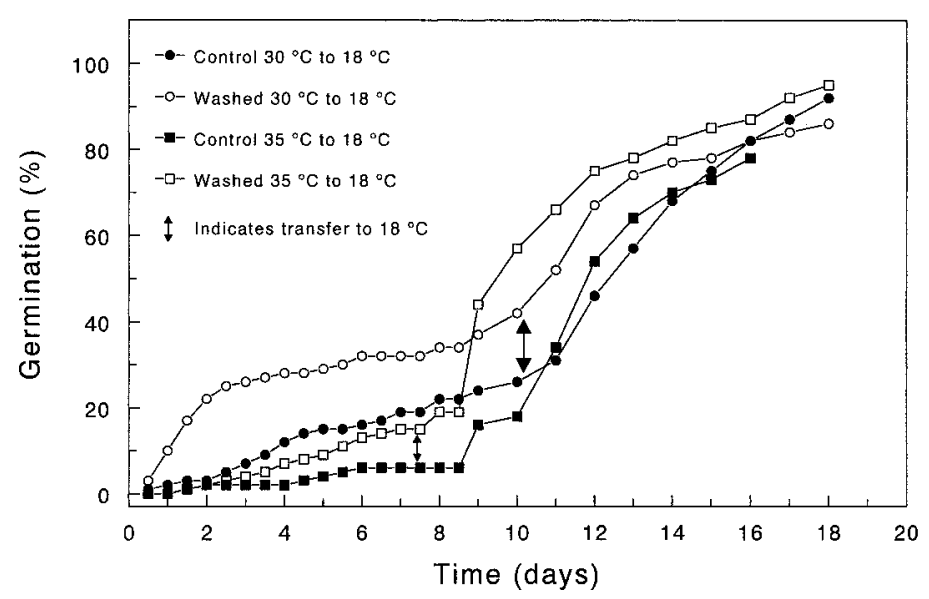

Fig. 3. Germination of 'Cascade' untreated control and washed seeds incubated at a constant $30^{\circ} \mathrm{C}$ for $10 \mathrm{~d}$ or $35^{\circ} \mathrm{C}$ for $7 \mathrm{~d}$, and then transferred to $18^{\circ} \mathrm{C}$ for a total incubation time of $20 \mathrm{~d}$.

glucopyranoside and by comparing the retention times with those of known standards of each saccharide of interest.

STATISTICAL PROCEDURES. Each temperature test was arranged in randomized complete block design, and each genotype was replicated four times. Fifty seeds were used in each replication. Seeds were considered germinated when the radicle protruded $(\geq 2 \mathrm{~mm})$ from the pericarp. The number of germinated seeds was counted daily and total germination, time to $25 \%$ germination $\left(T_{25 \%}\right)$, and mean days of germination (MDG) were calculated. Because final percentage germination varied widely in the alternating temperature tests, $T_{25 \%}$ was used instead of $T_{50 \%}$. Percentage of germination was transformed to square root arcsine prior to performing an analysis of variance. Data were analyzed using PROC GLM and PROC REG of SAS (SAS Institute, Inc., Cary, N.C.). Means were separated by LSD (0.05). The main effect of exogenous ABA concentration was partitioned into linear or quadratic orthogonal contrasts. In those experiments where significant interactions $(P \leq$ $0.05)$ were detected for germination, they were partitioned for each genotype.

\section{Results and Discussion}

Germination AT CONSTANT AND ALTERNATING TEMPERATURES. Germination percentage was highest between 10 and $20^{\circ} \mathrm{C}$, and inhibition occurred at temperatures higher than $20^{\circ} \mathrm{C}$ for 'Cascade' and 'ACX 5044' and at higher than $23^{\circ} \mathrm{C}$ in 'Fall Green' (Fig. 2). After $14 \mathrm{~d}$ of incubation at $30^{\circ} \mathrm{C}$, total germination ranged from less than $10 \%$ for 'Cascade' to between $40 \%$ and $55 \%$ for 'ACX 5044' and 'Fall Green' respectively, and was totally suppressed at $35^{\circ} \mathrm{C}$ in 'Cascade' and 'ACX 5044' (Fig. 2). Similarly, rates of germination (data not shown) were reduced at temperatures higher than 20 ${ }^{\circ} \mathrm{C}$.

Thermoinhibition was less pronounced at alternating temperatures compared to constant $30^{\circ} \mathrm{C}$ (compare Table 1 with Fig. 2). Germination was higher at $25 / 15^{\circ} \mathrm{C}, 30 / 15^{\circ} \mathrm{C}, 30 / 20{ }^{\circ} \mathrm{C}$ and $35 /$ $20^{\circ} \mathrm{C}(12 / 12 \mathrm{~h})$ than at $35 / 15^{\circ} \mathrm{C}$ or $35 / 25^{\circ} \mathrm{C}$ (Table 1$)$. Therefore, $20{ }^{\circ} \mathrm{C}$, rather than 25 or $15{ }^{\circ} \mathrm{C}$, improved germination when alternating with $35^{\circ} \mathrm{C}$ for $12 \mathrm{~h}$. The $T_{25 \%}$ was generally faster for 'Fall Green', than 'ACX 5044' and 'Cascade' at almost all alternating temperatures.

When seeds of 'Cascade', the spinach genotype most sensitive to high temperature, were incubated at $30^{\circ} \mathrm{C}$ for $10 \mathrm{~d}$, germination was only $23 \%$, but after being transferred to $18{ }^{\circ} \mathrm{C}$ for an additional $10 \mathrm{~d}$, germination proceeded and reached $88 \%$ (Fig. 3, control 30 $\left.{ }^{\circ} \mathrm{C}\right)$. Similarly, germination of Cascade seeds was reduced to $3 \%$ at $35^{\circ} \mathrm{C}$ after $7 \mathrm{~d}$, but increased to $75 \%$ after being transferred to $18^{\circ} \mathrm{C}$ for an additional $13 \mathrm{~d}$ (Fig. 3 , control $35^{\circ} \mathrm{C}$ ). This indicates that 'Cascade' spinach seeds held at supraoptimal temperatures can maintain the ability to germinate when returned to lower

Table 2. Germination of spinach genotypes at $30^{\circ} \mathrm{C}$ when subjected to various pericarp (P) modifications.

\begin{tabular}{|c|c|c|c|c|c|}
\hline Genotype & $\begin{array}{c}\mathrm{P} \\
\text { removed }\end{array}$ & $\begin{array}{c}\mathrm{P} \\
\text { removed } \\
\text { embryo }^{z}\end{array}$ & $\begin{array}{l}\text { P removed } \\
+ \text { embryo } \\
\text { reinserted }\end{array}$ & $\begin{array}{l}\text { P slitted } \\
\text { to } \\
1-2 \mathrm{~mm}\end{array}$ & $\begin{array}{c}\text { Intact } \\
\text { seed } \\
\text { (control) }\end{array}$ \\
\hline & \multicolumn{5}{|c|}{ Germination (\%) } \\
\hline ARK 88-354 & 92 & 92 & 87 & 71 & 65 \\
\hline Fall Green & 99 & 95 & 81 & 32 & 9 \\
\hline ACX 5044 & 96 & 83 & 69 & 18 & 1 \\
\hline Cascade & 96 & 87 & 66 & 9 & 1 \\
\hline $\operatorname{LSD}_{(0.05)}$ & --- & 5 & 13 & 29 & 18 \\
\hline
\end{tabular}

${ }^{\mathrm{z}} \mathrm{P}$ removed embryo $=$ pericarp removed and placed on the same medium at a distance of $\leq 5 \mathrm{~mm}$, but not touching the embryo. 
Table 3. Germination of pericarpless spinach seeds 'ARK 88-354' and 'Cascade' in contact with ABA solutions. Germination test was performed in petri dishes at $30^{\circ} \mathrm{C}$ in darkness for 1 week.

\begin{tabular}{|c|c|c|c|c|}
\hline \multirow[b]{2}{*}{$\begin{array}{l}\text { ABA } \\
(\mathrm{M})\end{array}$} & \multicolumn{2}{|c|}{ ARK 88-354 } & \multicolumn{2}{|c|}{ Cascade } \\
\hline & $\begin{array}{c}\text { Germination } \\
(\%)\end{array}$ & $\begin{array}{l}\mathrm{MDG}^{\mathrm{z}} \\
\text { (d) }\end{array}$ & $\begin{array}{c}\text { Germination } \\
(\%)\end{array}$ & $\begin{array}{l}\text { MDG } \\
\text { (d) }\end{array}$ \\
\hline 0 (Control) & 92 & 1.5 & 91 & 2.7 \\
\hline $10^{-6}$ & 90 & 1.7 & 87 & 2.4 \\
\hline $10^{-5}$ & 88 & 1.6 & 90 & 2.9 \\
\hline $10^{-4}$ & 91 & 2.3 & 34 & 3.4 \\
\hline $10^{-3}$ & 59 & 2.6 & 16 & 3.1 \\
\hline \multicolumn{5}{|l|}{ Orthogonal contrasts } \\
\hline Control vs. others & NS & $* *$ & $* *$ & NS \\
\hline $\mathrm{ABA}$ & $\mathrm{Q}^{*}$ & $\mathrm{Q}^{* *}$ & $\mathrm{Q}^{* *}$ & $\mathrm{~L}^{* *}$ \\
\hline
\end{tabular}

${ }^{\mathrm{z}} \mathrm{MDG}=$ mean days to germination.

Ns,*,** Nonsignificant or significant $\mathrm{F}$ test at $P=0.05$ or 0.01 , respectively. ABA concentration effect was linear (L) or quadratic (Q).

temperatures. Germination of washed 'Cascade' seeds increased to $38 \%$ at $30{ }^{\circ} \mathrm{C}$ for $11 \mathrm{~d}$ and to $12 \%$ at $35^{\circ} \mathrm{C}$ after $7 \mathrm{~d}$, and this improvement was carried over when seeds were transferred to 18 ${ }^{\circ} \mathrm{C}$ (Fig. 3, washed).

Pericarp role on germination. The germination of intact seeds held at $30^{\circ} \mathrm{C}$ for 1 week was very low in 'Cascade', 'ACX 5044', and 'Fall Green', although germination of 'ARK 88-354' reached $65 \%$ (Table 2). However, germination of embryos with the pericarp removed was similar to that for intact seeds at $\leq 20{ }^{\circ} \mathrm{C}$ temperatures (compare Table 2 with Fig. 2).

When seeds were incubated with the pericarp near the embryo, germination was slightly reduced in 'ACX 5044' and 'Cascade' compared with 'ARK 88-354' and 'Fall Green'. This decrease was more evident when embryos were reinserted back into pericarp (Table 2). Apparently, both structural and chemical factors in the pericarp prevented spinach germination at high temperature. Although $\mathrm{O}_{2}$ supply was reported to be critical for spinach embryos to germinate at high temperatures (Heydecker and Orphanos, 1968), in this study, slitting the pericarp had little effect on improving germination (Table 2).

Germination With EXogenous aba AND LEACHATE. 'Cascade' embryos were sensitive to ABA concentration; germination was significantly reduced to $16 \%$ at $10^{-3} \mathrm{M} \mathrm{ABA}$ and mean days of germination increased linearly from 2.4 to $3.1 \mathrm{~d}$ as ABA concentrations increased from $10^{-6}$ to $10^{-3} \mathrm{M}$ (Table 3 ). Germination of 'ARK 88-354' pericarpless seeds was reduced to $59 \%$ at $10^{-3} \mathrm{M} \mathrm{ABA}$, and mean days of germination increased by $0.9 \mathrm{~d}$ from $10^{-6}$ to $10^{-3} \mathrm{M}$ ABA. In rape (Brassicanapus L.), 10 ${ }^{-3} \mathrm{M}$ ABA completely inhibited germination (Schopfer and Plachy, 1984).

The ABA content of the pericarp (fresh weight basis) was $\approx 2.4$ fold higher in 'Cascade' and 'ACX 5044', 29 and $31 \mathrm{ng} \cdot \mathrm{g}^{-1}$ fresh weight, respectively $\left(\approx 1.2 \times 10^{-7} \mathrm{M}\right)$ than in 'Fall Green' and 'ARK 88-354' (Fig. 4). However, the content of ABA in the leachate was not consistently higher in the first two cultivars. Leaching removed up to $90 \%$ of ABA in 'Fall Green' and 'ARK 88-354' and between $20 \%$ to $50 \%$ in 'Cascade' and 'ACX 5044', respectively (Fig. 4). This may indicate that ABA was present in the apoplasm in 'Fall Green' and 'ARK 88-354'.

Washing significantly improved germination at $30^{\circ} \mathrm{C}$ only in 'Fall Green', whereas leachates inhibited germination significantly only in 'ACX 5044' (Fig. 5). The genotype 'ARK 88-354' appeared least sensitive to either the presence or absence of other possible inhibitors that might be present in the leachates. Germination of embryos was not affected when seeds were incubated with the leachate coming from intact seeds (Fig. 5), evidence that the pericarp is necessary for thermoinhibition or that the concentration was not high enough (as shown in Table 3) to inhibit germination.

EFFECT OF 'CASCADE' PERICARPS ON 'ARK 88-354' EMBRYOS. Germination of 'ARK 88-354' embryos in 'Cascade' pericarp was $17 \%$ lower than 'ARK 88-354' embryos in 'ARK 88-354' pericarps. Conversely, germination of 'Cascade' embryos in 'ARK 88-354' pericarps was $13 \%$ higher and proceeded at a lower speed (2.4 vs.

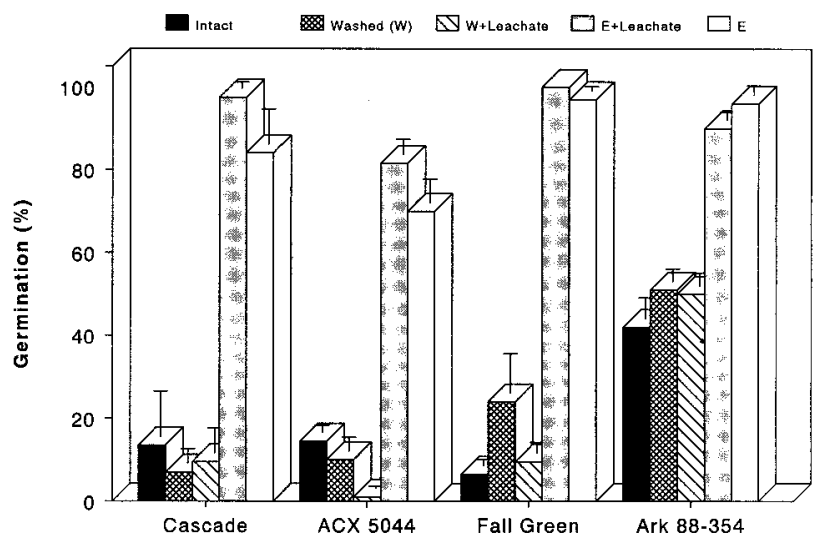

Fig. 4. ABA concentration (fresh weight basis) in pericarps and leachates from intact seeds of four spinach genotypes. Each bar represents a mean $(n=4) \pm$ SE.

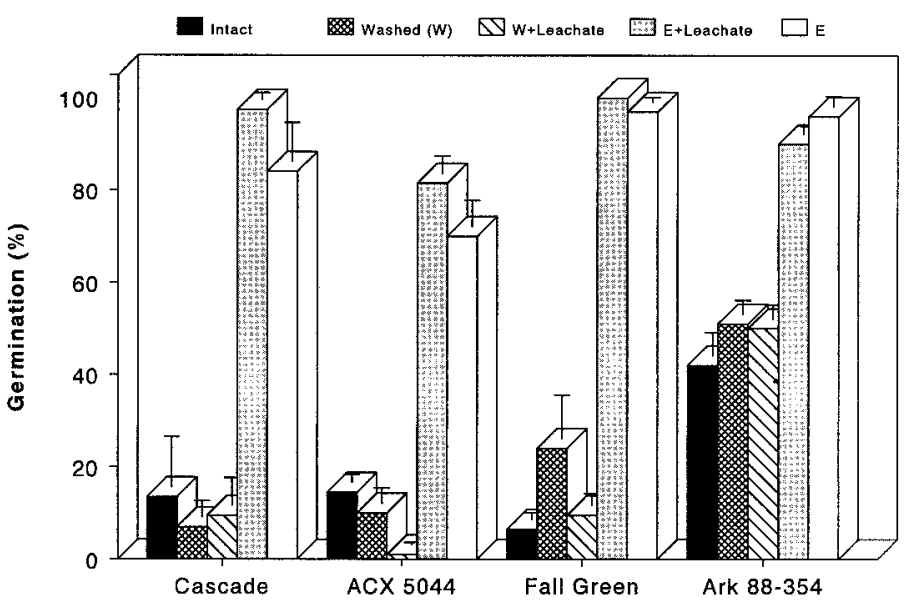

Fig. 5. Germination of spinach seeds at $30^{\circ} \mathrm{C}$ in the presence of seed leachates. Intact (intact seeds in deionized distilled water), $\mathrm{W}=$ washed or leached seeds in deionized distilled water, $\mathrm{W}+$ Leachate $=$ washed or leached seeds in leachates extracted from whole seeds of the same genotypes, $\mathrm{E}+$ Leachate $=$ embryo with perisperm in leachates from whole seeds, and $E=$ embryo with perisperm. Each bar represents a mean $(n=4) \pm$ SE. 
Table 4. Germination of spinach embryos incubated at $30{ }^{\circ} \mathrm{C}$ when reinserted to similar or different pericarps.

\begin{tabular}{lcc}
\hline \hline Treatment $^{\mathrm{z}}$ & MDG $^{\mathrm{y}}$ & $\begin{array}{c}\text { Germination } \\
(\%)\end{array}$ \\
\hline $\mathrm{Ae}+\mathrm{Cp}$ & $(\mathrm{d})$ & 76 \\
$\mathrm{Ae}+\mathrm{Ap}$ & 2.3 & 93 \\
$\mathrm{Ce}+\mathrm{Ap}$ & 2.1 & 76 \\
$\mathrm{Ce}+\mathrm{Cp}$ & 2.4 & 63 \\
$\mathrm{LSD}_{(0.05)}$ & 3.3 & 10
\end{tabular}

${ }^{\mathrm{z}} \mathrm{Ae}+\mathrm{Cp}=$ 'ARK 88-354' embryo reinserted into ‘Cascade’ pericarp; Ae $+\mathrm{Ap}=$ 'ARK 88-354' embryo reinserted into 'ARK 88-354' pericarp; Ce $+\mathrm{Ap}=$ 'Cascade' embryo reinserted into 'ARK 88-354' pericarp; Ce + Cp = 'Cascade' embryo reinserted into 'Cascade' pericarp.

${ }^{\mathrm{y}} \mathrm{MDG}=$ mean days to germination.

3.3 d) compared to 'Cascade' embryos in 'Cascade' pericarps (Table 4). Therefore, this result confirms the greater inhibitor capacity of 'Cascade' pericarps. Increased germination as a result of pericarp removal were reported in 'Prickly New Giant' spinach; however, the germination level of that genotype did not reach those found at optimum temperatures (Atherton and Farooque, 1983a), such as reported in our study.

Soluble CARBOHYDRATES. The major sugars present in spinach seeds imbibed at $30^{\circ} \mathrm{C}$ for $96 \mathrm{~h}$ were the monosaccharide glucose (Glu), and the di- and tri-oligosaccharides sucrose (Suc) and raffinose (Raf), respectively. In addition, myo-inositol was also detected. Glu content of 'Fall Green' seeds remained unchanged until $24 \mathrm{~h}$; thereafter, Glu amounts increased more rapidly than in 'ARK 88-354', while Glu content of 'Cascade' seeds remained low throughout the $96 \mathrm{~h}$ incubation (Fig. 6). Suc amounts were slightly higher in 'Fall Green' and 'ARK 88-354' compared to 'Cascade' seeds at 72 h. At 96 h, however, Suc levels in 'Fall Green' were 4-fold greater than the other two genotypes. Prior to imbibition $(0 \mathrm{~h})$ Raf content was significantly different among the three genotypes and was in the order of 'ARK 88-354' > 'Fall Green' > 'Cascade'. After 48 h, Raf levels declined in 'Fall Green' compared to 'ARK 88-354'. In 'Cascade', Raf levels remained about constant after $24 \mathrm{~h}$ and higher than the other two genotypes after 36 h. Myo-inositol was highest for 'ARK 88-354' only at noticeable peaks at 16 and $72 \mathrm{~h}$ imbibition. At $36^{\circ} \mathrm{C}$, Glu, Suc, and myo-inositol levels were negligible and remained fairly unchanged in the three genotypes (Fig. 6). Raf declined immediately after imbibition, increasing 2 -fold at $96 \mathrm{~h}$ imbibition only for 'Cascade' seeds.

It is likely that for seeds imbibed past $36 \mathrm{~h}$ at $30{ }^{\circ} \mathrm{C}$ the hydrolysis of Raf into Suc and D-galactose contributed to a relative greater content of Suc and Glu in 'ARK 88-354' and 'Fall Green'. Since galactose was not detected, it is possible that it was metabolized for energy or transformed into sucrose. The decline of Raf in 'ARK 88-354' and 'Fall Green' could be associated with the onset of germination. The biosynthesis of Raf involves the successive transfer of a D-galactosyl residue from galactinol, which is formed from UDP-galactose and myo-inositol (Goodwin and Mercer, 1983). Whether increases in myo-inositol in 'ARK 88-354' are important for the synthesis of additional Raf beyond $96 \mathrm{~h}$ is unknown. In 'Cascade' seeds, Raf content decreased less rapidly than in 'ARK 88-354' and 'Fall Green'.

Endo- $\beta$-mannanase and $\alpha$-galactosidades are two important enzymes capable of mobilizing soluble sugars, decreasing the mechanical restraint imposed on the tomato embryos (Groot et al., 1988; Hilhorst and Downie, 1996). Mannose activity and synthesis can be suppressed by ABA (Malek and Bewley, 1991). Whether the activity of these enzymes is greater in 'Fall Green' and 'ARK 88-354' than in 'Cascade' and 'ACX 5044' seeds is unknown. ABA content in the seedcoat was leached easily in 'Fall Green' and 'ARK 88-354', but not in the other two genotypes. We could speculate that if levels of ABA were measured and found to be high either in the perisperm or the embryonic axis in the sensitive genotypes, ABA could be another component of the inhibitory system, altering the seed metabolism, e.g., by suppressing the activity or synthesis of endo- $\beta$-mannanase or delaying seed germination until seeds encounter lower temperatures such as observed for 'Cascade' (Fig. 3).

In a recent overview of primary dormancy in tomato, Hilhorst (1997) described that all seed parts, including the thin testa may play a major role in seed dormancy. During seed germination inhibition in Chenopodium album L., a species that, like spinach, belongs to the Chenopodiaceae, one site of secondary hormonal action was located inside the covering structures where $\mathrm{ABA}$ blocks GA-induced hydrolysis of the endosperm (Bewley and Black, 1994; Karssen 1976). Based on our studies in spinach we do not have enough evidence to explain the inhibitory effect on the basis of ABA alone since the concentration of ABA in the seedcoat was too low ( $\left.30 \mathrm{ng} \cdot \mathrm{g}^{-1}\right)$ to inhibit germination. Karssen (1976) concluded that ABA had no function in the regulation of dormancy in C. album seeds, containing 8 to $10 \mathrm{pg}$ ABA/seed, a much lower concentration than measured in the seedcoats in our study.

The differential responses of seed germination to high temperatures among the genotypes used in this study could also be related to the different genetic background of each cultivar. For

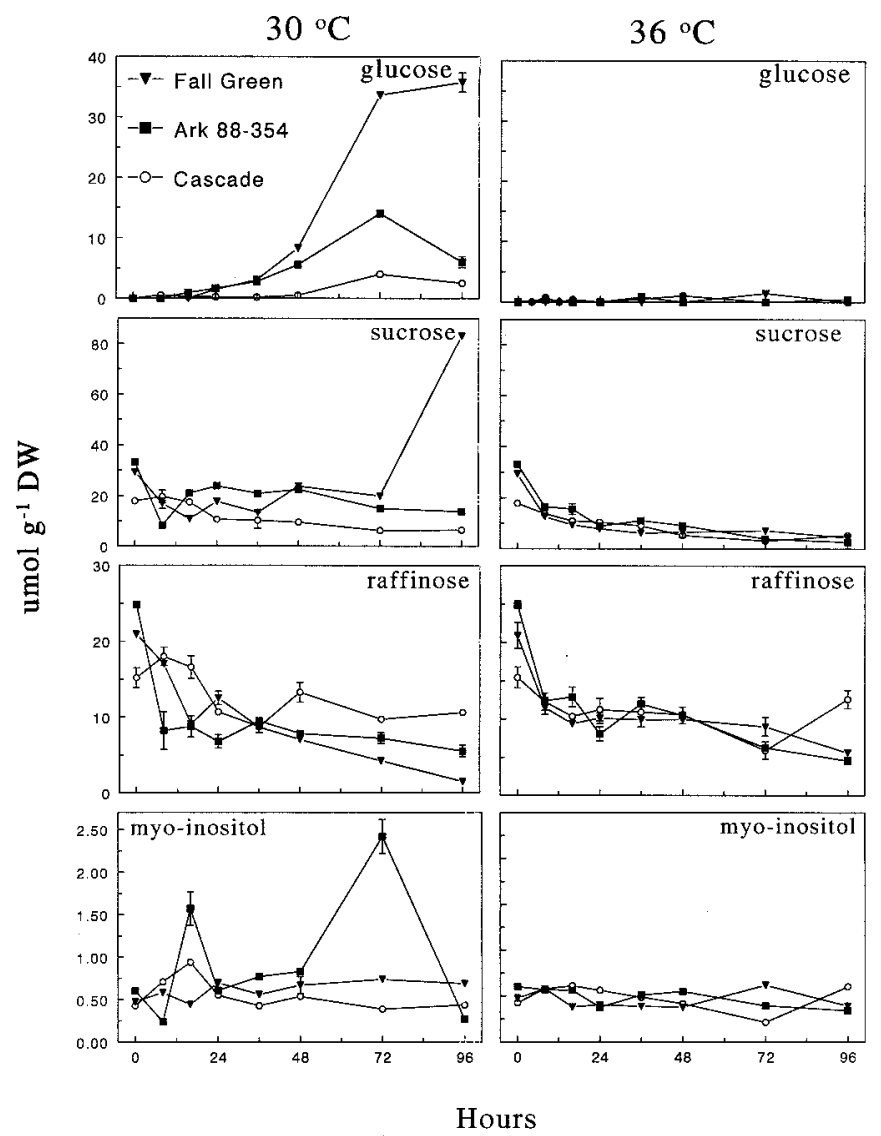

Fig. 6. Glucose, sucrose, raffinose, and myo-inositol concentrations (dry weight basis) in 'Fall Green', 'ARK 88-354', and 'Cascade' spinach seeds imbibed at 30 and $36{ }^{\circ} \mathrm{C}$ for $96 \mathrm{~h}$ 
example, 'ARK 88-354' is an open-pollinated smooth leaf cultivar developed by selecting seedlings of segregating material from 'Fall Green', an open-pollinated savoy leaf type cultivar, followed by intercrossing with superior flat leaf plants ( $T$. Morelock, University of Arkansas, personal communication). Both cultivars exhibited similar levels of ABA in the pericarp and leachate fraction (Fig. 5). The hybrids 'Cascade' and 'ACX 5044', genetically dissimilar to 'Fall Green', share the same male but not the female parent. The pericarp that surrounds the embryo and perisperm is part of the diploid mother plant and therefore genetically different from the diploid embryo. In addition to genetic factors, further investigations are needed to elucidate the effect of environmental conditions during spinach seed development and maturation on pericarp structure, ABA, non hormonal inhibitor compounds, and the presence of enzymes capable of mobilizing soluble sugars during seed germination.

\section{Literature Cited}

Atherton, J.G. and A.M. Farooque. 1983a. High temperature and germination in spinach. I. The role of the pericarp. Scientia Hort. 19:27-32. Atherton, J.G. and A.M. Farooque. 1983b. High temperature and germination in spinach. II. Effect of osmotic priming. Scientia Hort. 19:221227.

Belefant, H. and F. Fong. 1989. Abscisic acid ELISA: Organic acid interference. Plant Physiol. 91:1467-1470.

Benech Arnold, R.L., C.M. Ghersa, R.A. Sanchez, and P. Insausti. 1988. The role of fluctuating temperatures in the germination and establishment of Sorghum halepense (L.) Pers. Regulation of germination under leaf canopies. Funct. Ecol. 2:311-318.

Bernal-Lugo, I. and A.C. Leopold. 1992. Changes in soluble carbohydrates during seed storage. Plant Physiol. 98:1207-1210.

Bewley, J.D. and M. Black. 1994. Seeds: Physiology of development and germination. 2nd ed. Plenum Press, New York.

Cantliffe, D.J., J.M. Fisher and T.A. Nell. 1984. Mechanism of seed priming in circumventing thermodormancy in lettuce. Plant Physiol. 75:290-294.
Crozier, A., G. Sandberg, A.M. Monteiro, and B. Sundberg. 1985. The use of immunological techniques in plant hormone analysis, p. 13-21. In: M. Bopp (ed.). Plant growth substances. Springer-Verlag, Berlin. Goodwin, T.W. and E.I. Mercer. 1983. Introduction to plant biochemistry. Pergamon Press, NewYork.

Groot, S.P.C., B. Kieliszewska-Rokicka, E. Vermeer, and C.M. Karssen. 1988. Gibberellin induced hydrolysis of endosperm cell wall in gibberellin-deficient tomato seeds prior to radicle protrusion. Planta 174:500 504.

Hassell, R.L. and D.W. Kretchman. 1997. The effects of umbel order, soaking, and scarification on germination inhibiting substances in Petroselinum crispum L. and other Apiaceae seeds. HortScience 32:1227-1230.

Heydecker, W. and P.I. Orphanos. 1968. The effect of excess moisture on the germination of Spinacia oleracea L. Planta 83:237-247.

Hilhorst, H.W.M and B. Downie. 1996. Primary dormancy in tomato (Lycopersicum esculentum cv. Moneymaker): Studies with sitiens mutant. J. Expt. Bot. 47:89-97.

Hilhorst, H.W.M. 1997. Primary dormancy in tomato. Further studies with the sitiens mutant, p. 191-201. In: R.H. Ellis, M. Black, A.J. Murdoch, and T.D. Hong (eds.). Basic and applied aspects of seed biology. Kluwer Academic Publishers.

Karssen, C.M. 1976. Two sites of hormonal action during germination of Chenopodium album seeds. Physiol. Plant. 36:264-270.

Koster, K.L. and A.C. Leopold. 1988. Sugars and dessication tolerance in seeds. Plant Physiol. 88:829-832.

Malek, L. and J.D. Bewley. 1991. Endo- $\beta$-mannanase activity and reserve mobilization in excised endosperm of fenugreek affected by volume of incubation and abscisic acid. Seed Sci. Res. 1:45-49.

Masuda, M. and K. Konishi. 1993. Improvement of high-temperature germination of spinach seed with acid scarification and priming with polyethylene glycol 6000. J. Jpn. Soc. Hort. Sci. 62:419-424.

Schopfer, P. and C. Plachy. 1984. Control of seed germination by abscisic acid. II. Effect on embryo water uptake in Brassica napus L. Plant Physiol. 76:155-160.

Vertucci, C.W. and J.M. Farrant. 1995. Acquisition and loss of dessication tolerance, p. 237-271. In: J. Kigel and G. Galili (eds.). Seed development and germination, Marcel Dekker Inc., New York. 